\title{
The Significance of Modern Writers of Turkey and Their Influence on Contemporary English
} Novel

\author{
Showket Ibraheem Bakheet Almuhamedy ${ }^{1}$, Najim Abdullah Hammood ${ }^{2}$, \\ Samer Dhahir Mahmood ${ }^{3}$
}

\author{
${ }^{1}$ Al Salam University College, Baghdad, Iraq \\ Showket1982@yahoo.com \\ ${ }^{2}$ Minstery of Education, Al Anbar, Iraq \\ rami1976er@gmail.com \\ ${ }^{3}$ Minstery of Education, Al Anbar, Iraq \\ dhahirsamer@gmail.com
}

\begin{abstract}
Nazim Hikmet (1902 to 1963) and Yasar Kemal (1923 -) were regarded as significant modern writers of Turkey. They have contributed to the literary significance of Turkish poetry in the world literature. The literary contributions of these authors have revealed Turkey's vibrant literary scene and legacy within the world literature. The works delivered by them have influenced the literary lovers and even contemporary writers of Turkey with their resemblance of literary style. The works delivered by these writers have nominated them for the noble prize. The poetry and literary contributions of these modern writers of Turkey are significant with unique writing style mixed with romantic flavor and humorous touch. The modern writers have narrated the culture and fiction of Eastern and Western heritage. The versatile writing style was enriched with fiction combined with romantic flavor with vibrant literary scene with magical realism and folklore. In this paper we are presenting the trends of modern writers of turkey influenced the narrating and writing style of contemporary writers. The writing style, culture, fiction and romantic touch of modern writers are inherited by Nazim Hikmet and Yasar Kemal. The influential factors of these writers have discussed in this paper.

Keywords-Modern literature, romantic communism, Uniqueness in writing style, the influence of modern writers.
\end{abstract}

\section{INTRODUCTION}

Nâzım Hikmet Ran was famed as Turkish poet, play writer, novelist, screenwriter, director and memoirist. He studied in University of Moscow and adopted the Marxist doctrines. He was famed as a romantic communist and romantic revolutionary writer. His poetry was very famous and translated into more than 50 other national and foreign languages. His famous works are "I come and stand at every door", "On the soldier worth 23 cents" and "Atomic bombings of Hiroshima and Nagasaki". Apart from this literature, he contributed more than 124 literary works and poetry. He wrote plays, Ballet Libretto, Novels, Poems, Poetry and translated works from English. His poetry has fascinated the people of Turkey and translated to other foreign languages. He became a revolutionary hero of the Turkish literature.

Yasar Kemal was a Kurdish writer wrote many English novels, children Novels, Epic Novels, Novels and short stories and memories. He received nearly 38 awards and nominated as a candidate for noble prize for his famous literary works "Ince Memed" and "My Hawk". These two novels have reflected the common man exasperation and hopelessness of mankind. He depicted these literary works with solvation of human problems from the myths and legends. His literature was reflecting the traces of Anatolian folk literature. His stories and works are reflecting the lifestyles and culture of Anatolia. His works are reflecting the reality of lifestyles, prolonged descriptions of nature, surroundings, culture and predominant flavor of humanity and mankind. Most of the novels are reflecting the nature, culture, sentiment and victory from the innocent nature with great belief on the myths and legends of village background. His children stories were enriched with adventurous myths, fiction, and supernatural events with village background. His novels give great relief to the readers when they are in depression and havoc. The novels used to generate an unstoppable interest and great relief to the readers by narrating the 
supernatural concepts and romance mixed with myths and legends around the angels and princes.

The writers highlighted the social cause, social responsibility, human equality, moral values and mankind were the predominant in their literary works.

\section{RELATED WORK}

In the novel "A Portrait of the Artist as Filipino" The author gives more stress on Feminism. Most of the scenes in this novel are reflecting the freedom for women and the importance for social responsibility and honor to women. This book has illustrated the socio-economic conditions of the women who did not get married. This book has illustrated the struggle and fatigue what the women in society is facing individually. This novel has represented the social status of two sisters when they are assuming without their father's support. (Nick Joaquin (1950))

The novel from Modern writers was "Voyeurs \& savages". This novel has illustrated the view and behaviors of men towards women. This book has illustrated the polished nature of reputed men in society. This novel has depicted the peeping tom culture of the polished men in society with reputation. This novel represented a woman who can argue with her hand uncle about the equal rights and opportunities in society. This novel has illustrated the scenes with great human and generated the interest in the story. Alfred A. Yuson (1998)

The latest novel named "Twentieth-Century Women's Literature: Exploration of Female-identity and Expressions of Independence, Autonomy and Self-assertion" is the novel which has narrated the importance of the women in the developing society. In this novel the author has focused the supremacy of women in every field. The importance of women in every competition politically, economically, technically and in the field of entrepreneurship. This novel has won several awards for representing the Feminism in a beautiful manner to attract more readers. (Raisa Tamanna Khan (2012))

The latest and famous book "Feminism in Literature the Feminist Movement in the 20th Century" has directly illustrated the Feminism in her literature. This book as exemplified the status of the women with predominant positions in the word. This book has illustrated the prime minister to entrepreneurs in the society with proven track record. This book has illustrated the importance of women with predominant history and victorious track record. (Bella Abzug (2018)).

The award-winning book named "A Companion to Modernist Literature \& Culture" has beautifully described the importance of women in the family front, business front, political stature with outstanding performance. This book has illustrated the women culture and behavior with neat and clean description. The books generated the great interest in the readers with spontaneous interest. This novel is a best replication of literature with feministic culture and equality of women. (Lavoine, Samantha. (2006))

Lexical Bundles are another predominant feature of modern literature writer. In the modern writers of English literature developed from Turkey have replicated the lexical bundles. These novels and works have replicated lexical bundles while illustrating the fiction, hummer and socio-economic conditions. The students have learned the statistical analysis to find the significant use of lexical bundles in their works (Yusuf et.al (2016)).

These novels developed with the fiction, adventure, realistic incidents, deception, exploitation, humor, romance and feminism. The literary works of Nazim Hikmet and Yasar Kemal have influenced the readers with great deal of interest and favoritism. The novels of these writers were depicting the story with heartbreaking twists, revolutionary democracy, adventurous actions, strikingly direct to the minds of the readers. The predominant writing style was influenced the modern writers of Turkey and created many novels and short stories with novel themes.

\section{INFLUENCE OF MODERN WRITERS}

The most significant nature can be seen in the contemporary writers are humor and romantic touch in writing. Most of the famous contemporary writers are framing their literary works with feminism, great deal of human equality, humor and romantic touch to attract the readers. In addition to that the modern writers of Turkey have inculcated the critical approach with new and useful world concepts. Nazim Hikmet (1902 to 1963) and Yasar Kemal belonged to the pre-independence period. The modern writers are post-independence period and writing the literary works which can reflect the contemporary trends of the world. The following works of the contemporary writers can reflect the facts.

The best seller of English novel from Turkish writers is "Madonna in a Fur Coat". This book has represented a shy woman brought up from turkey and moved to Berlin. The young and shy women have experienced the great pressure to give up her shy and developed as the famous star in the world. This novel has attracted most of the readers in the world and become the best seller of the decade. This book has illustrated the boldness and leadership qualities of a rural women from turkey and learned the lessons to take supremacy in the segment of pop singers of the world. (Sabahattin Ali (2017)). The award-winning quality has been acquired from the writing style of Nazim Hikmet and 
Yasar Kemal, the English Novelists of Turkey. The feminism flavors have been adopted by the writings of Nazim Hikmet and Yasar Kemal Turkish and demonstrated in the novels. The feministic thoughts and culture have been imported from these writers and their outlook. The success of the books is basically happened with the hummer mixed interest generation writing in the contemporary world is predominant in this book. The contemporary English novelists from Turkey have replicated the flavors of modern English writers vies and ideology. Predominantly Feminism is represented in the latest novels and achieved outstanding sales with remarkable quality.

\section{CONTEMPORARY TURKISH NOVELISTS}

Pelin Batu is an actress, poet, historian of Turkey born in 1978 and producing several works with quality. Her novels are representing the equal rights of women. Pelin has reflected the humor and romantic flavor in her writing (Pelin Batu (2012)). She was also influenced by the writing style and influenced by the themes of the writers Nazim Hikmet and Yasar Kemal.

Attilâ İlhan is a contemporary significant Turkish poet, novelist, essayist, journalist and reviewer born in 15 June 1925 and died on10 October 2005. Wrote many awardwinning novels in English. The novels and works have replicated the feminism and socio-economic growth of the women. The Man on the Street, Black Men Don't Look Alike and Tip of the Knife are predominant among the works delivered by the author. Attila has been influenced by the modern writers of turkey and resembled the writing style with humor and social status of Eastern and Western culture. Attilâ İlhan was also influenced by the writing style and themes of Nazim Hikmet and Yasar Kemal. Nazim Hikmet and Yasar Kemal writing style was reflecting the humor, romance, great democratic thoughts and human values. The same were influenced the modern author Attilâ İlhan. Basically, he was influenced by the writing style and theme depiction of Yasar Kemal.

Yasar Kemal was a famous novelist from Turkey died on 28th February 2015. His remarkable works are Ballads debut, Memed My Hawk, the Drumming-Out, They Burn the Thistles. In his works and novels, he never hesitated to express his opinion on the sensitive issues of society. He is regarded as the strong feministic culture writer who has equal gender opportunities in the socio-economic status. In his novels the flavor of romantic touch and humor are associated to generate the interest of the reader (Kemal, Memed (2005)).

Aşık Mahzuni Şerif (2002) was a famous folk musician, ashik, poet and composer born in1940 and died in 2002.
His remarkable works have replicated the rural folk culture and gender equality. Though he wrote a small number of books his books were famed in the society for its versatility with the flavor of humor and romantic touch (Aşık Mahzuni Şerif (2002)).

The writing style of Asik Mahzuni Serif was reflecting the versions of Nazim Hikmet and Yasar Kemal. He adopted the rural culture and village background from Nazim Hikmet and Yasar Kemal and depicted the fiction in rural folk culture. Basically, Nazim Hikmet and Yasar Kemal gave predominant importance for Feminism and gender equality. The same can be found in the writings of Așik Mahzuni Şerif.

Ahmet Hamdi Tanpınar is a predominant writer of modern Turkish literature. He was famed as an English Poet, Novelist, scholar and good essayist. His famous contemporary book the time regulation institute has been regarded as the best books of the decade by the culture trip. In his novels, the feminism and gender equality are highlighted. The novels have attracted the readers with great following. The novels are written with the humor, romantic and fantasy flavor (Ahmet Hamdi Tanpınar (2012)).

The writing style of Ahmet Hamdi Tanpinar was influenced by the writing style and narrative swiftness of Yasar Kemal and Nazim Hikmet. The romantic touch. The style of depicting the story, comprised with democratic feelings and human values are inherited and adopted from Yasar Kemal and Nazim Hikmet.

Hakan Günday (2012) is a famous writer in Turkish and English literature. His predominant book "More "has been selected as the best book of the international literature. The book has represented the hardworking nature of women who inspired the son to become famous. This book has represented the heroic works of the men but inspired by the women in the society. His works are predominantly identified as the best sellers of the international readers. The great following has been observed with these books are enriched with the flavor or romantic and humorous touch (France, P., (2016)).

His writings were exemplifying the writing style of Nazim Hikmet and Yasar Kemal. His predominant themes in short stories were enriched with human themes and human values. This kind of writing style and elevation of human values and women equality were influenced by Nazim Hikmet and Yasar Kemal themes of their novels and short stories (Osman Sahin (2003)).

\section{WRITING STYLE OF NAZIM HIKMET AND YASAR KEMAL}


It is clearly observed that the writing style of Nazim Hikmet and Yasar Kemal were enriched with the national culture with a revolutionary and criticizing eye. The literature works have influenced broadly with the human values and mankind were predominantly be raised in the readers. This culture generated a change in the human perceptions and life style change. Especially Nazim Hikmet was famous for folk poetry and classical Turkish poetry. He adopted the trends of world poetry and used to depict the elements of the eastern and western poetry. His literature works were reflecting the doctrines of Russian futurists and constructivists. He crystallized the sources of his writings and refined the concepts with a critical eye and injected into his poetry. The themes of his literary works were creating the social responsibility and human values with the writings of his novels and stories. This writing style was predominantly influenced the modern writers of English literature. The modern English writers of Turkey were developing the characters with the moral values and humanism and universalism (Marian Aguiar (2007)).

The Turkish literature was influenced in three periods. These are namely adoption of Islam, the Islamic period and the period under western influence. The writings of Nazim Hikmet and Yasar Kemal were considered to be the literature works of the third period of influenced by western influence and Islamic period. But the works given by these two authors reflected the strong need for democracy and human values. The writings of these authors were strongly demanding the reader to have a social responsibility to react for the evil in the society and betrayal (Marian Aguiar (2007)). The writing style was mixed with adventurous twists combined with the social, economic and political reforms. The revolutionarydemocratic reflections ware probing to achieving social change until the proclamation of the Republic. It can be seen obviously in the literary works of Nazim Hikmet and Yasar Kemal. In their literary period Turkey achieved the Republic and the democratic thoughts were inherited by the modern writers could adopted the humanitarian grounds, feminism, gender equalism and moral values combined with Western culture and Eastern culture (Qaisar Abbas (2013)).

\section{CONCLUSION}

The contemporary English Novelists from Turkey have predominantly famed with the story and outlook presentation of feminism in their novels. The modern writers of Turkey have presented the fantasy and rural ambiance, representation of nature and realistic life of the rural life. The modern writers have predominantly elevated the feelings and thrust of equal participation in society with their strength and vigor. Feminism was exemplified in the works of modern writers. The influence of feminism, humor, fantasy and equal participation in the society are represented in the contemporary writers and generated award-winning books in the $21^{\text {st }}$ century. The winning concepts have been taken from the ideology of modern writers like Nick Joaquin (1950), Alfred A. Yuson (1998) and other modern writers. The theme and story represented in the works presented by Raisa and Bella are representing the feminism and elevated culture of women in their works. The books have selected for the best sellers of the decade. The influence of feminism and women equal rights have been appreciated in their novels which are taken from the modern writers of English from Turkey.

\section{REFERENCES}

[1] Joaquin, N. (2017). The Woman Who Had Two Navels and Tales of the Tropical Gothic. Penguin.

[2] Kalangitan, D., Dula, L., Sulayman, T., Alimuddin, I., \& Kiram, M. L. T. History of the Philippines.

[3] Bradshaw, D., \& Dettmar, K. J. (Eds.). (2008). A companion to modernist literature and culture. John Wiley $\&$ Sons.

[4] Azra Abidi (2017). International journal of English language, literature in humanities. ISSN-2321-7065 Volume $\mathrm{V}$, Issue IV April 2017

[5] Bella Abzug (2018). The Feminist Movement in the 20th Century - $\quad$ Essay accessed https://www.enotes.com/topics/feminism/criticalessays/feminist-movement-20th-century

[6] Khan, R. T. (2012). Twentieth century women's literature: exploration of female-identity and expressions of independence, autonomy and self-assertion (Doctoral dissertation, BRAC University).

[7] Öztürk, Y., \& Köse, G. D. (2016). Turkish and native English academic writers' use of lexical bundles. Dil ve Dilbilimi Çalışmaları Dergisi, 12(1), 149-165.

[8] Topaloğlu, F. (2012). Şi'a'da Mehdi İnancının Oluşumunda Fars Kültürünün Etkisi. e-Makalat Mezhep Araştırmaları Dergisi, 5(2), 109-148.

[9] Kemal, Y. (2005). Memed, my hawk. New York Review of Books.

[10] TÜRKMENOĞLU, S. (2013). YERALTI EDEBIYYATI BAĞLAMINDA BİR KARŞILAŞTIRMA: DÖVÜŞ KULÜBÜ-KİNYAS VE KAYRA. Electronic Turkish Studies, 8(9).

[11] France, P. (Ed.). (2000). The Oxford guide to literature in English translation. Oxford University Press, USA.

[12] Gezeroğlu, S., \& Yivli, O. (2015). Nezihe Meriç'in öykülerinde kronotop (zaman-uzam) (Master's thesis, Nevşehir Hacı Bektaş Veli Üniversitesi).

[13] Liang, L., \& Xu, M. (2018). A Comparative Analysis of the Reception of Four English Versions of Fu Sheng Liu Ji: 
Translation, Publication and International Circulation. Translation Review, 101(1), 7-30.

[14] KUZUBAŞ, M., ŞAHIN, K., ERLER, M. Y., ŞIŞMAN, B., KOLAÇ, E., GÜNEŞ, M., ... \& DOĞAN, N. Uluslararası Sosyal Araştırmalar Dergisi The Journal of International Social Research Cilt: 9 Say1: 42 Volume: 9 Issue: 42 Şubat 2016 February 2016 www. sosyalarastirmalar. com Issn: 1307-9581.

[15] Aguiar, M. (2007). Nâzim Hikmet's Modernism of Development. Journal of Modern Literature, 30(4), 105121.

[16] Abbas, Q. (2013). Twin Poets Who Lived Apart: Nazim Hikmet and Faiz Ahmed Faiz. Pakistaniaat: A Journal of Pakistan Studies, 5(2), 139-148. 